\title{
Trajectories of land acquisition and enclosure: development schemes, virtual land grabs, and green acquisitions in Indonesia's Outer Islands
}

\author{
John F. McCarthy, Jacqueline A.C. Vel and Suraya Afiff
}

\begin{abstract}
While the size and speculative nature of land transactions in the wake of energy, food and climate crises have surprised observers, the reasons for partial implementation of many land developments remain largely unexamined. This contribution investigates trajectories of land acquisition and enclosure by analyzing four acquisition processes in Indonesia - those associated with rice, oil palm, Jatropha and carbon sequestration - considering their implications for comparative studies elsewhere. The paper finds that current patterns of land use change represent a continuation of ongoing land transformation processes. It describes the logic leading to partial realization of large-scale schemes. Highlighting the importance of interactions between formal and vernacular rural land development processes, the essay concludes that many large-scale schemes are better understood as virtual land acquisitions.
\end{abstract}

Keywords: land tenure; agrarian change; food security; biofuels; oil palm; forests; rice; climate change; Indonesia

\section{Introduction}

The magnitude and speculative nature of land transactions following the advent of energy, food and climate crises have surprised observers. Some analysts have suggested that up to as much as 227 million hectares (ha) have been sold, leased or licensed in large-scale land deals over the last decade (Oxfam 2011). This 'new bubble' involving speculative investments and large-scale land acquisitions (or 'land grabs') has inflated as investors seek to exploit new market opportunities for food crops, industrial cash crops and bio-energy production along with new enclosures of forest land for carbon sequestration (De Schutter 2011, Deininger 2011). Careful analysis, however, suggests that we need to avoid taking these figures at face value. To be sure, it is tempting to lump together disparate land transactions as 'land grabs'. This might suggest a kind of teleology: large corporations take over

This article is a product of collaboration between the authors within the framework of the research cluster 'JARAK: the commoditization of an alternative biofuel crop in Indonesia' as part of the program 'Agriculture beyond Food', with financing from the Royal Netherlands Academy of Sciences (KNAW), the Netherlands Organization for Scientific Research (NWO), and the Royal Netherlands Institute of Southeast Asian and Caribbean Studies ( KITLV). We would like to thank Jan Michiel Otto, our JARAK colleagues, Carol Warren, Bec Donaldson and two reviewers for their valuable comments. An earlier version of this paper was presented at the International Conference on Global Land Grabbing at Institute of Development Studies, Sussex University, April 2011. 
large areas for agricultural commodity production for export and for carbon sequestration while displacing peasantries in the local domain. This may resonate well with classical descriptions of the 'slow dissolution of the peasantry' as they are dispossessed by 'big land estate and large-scale agriculture' (Akram-Lodhi and Kay 2009, 7); and indeed, this dynamic can be found in specific cases. Yet only a fraction of land developments associated with these transactions are ever implemented. According to calculations from the World Bank (2011, 224), only 30 percent of developments are in the initial implementation stage. To date the reasons for postponement and failure of these projects remain largely unexamined.

This paper seeks to understand the logic underlying several different enclosure processes, examining the dynamics shaping each in turn. We also address the question of partial and non-implementation of apparently promising land acquisition plans. The cases discussed are from Indonesia, the largest country in Southeast Asia, where extravagant macro-economic, agribusiness and green agendas circulate around the new opportunities. According to reports, state planners have allocated up to 3.5 million ha for new food estates (Media Indonesia 2011), and there are plans for a further seven million ha of new oil palm plantations by 2020 (USDA 2010), alongside nine million ha of new timber plantations by 2016 (Obidzinski and Dermawan 2010). In addition the Ministry of Forestry aims to expand forest concession for non-gas and oil mining, to encompass 2.2 million ha of 'forest land' (Jakarta Globe 2010). This sits alongside ambitions to develop 1.5 million ha of Jatropha to meet the aspiration of making Indonesia 'the world's first biofuel superpower' (I-Newswire 2010). Meanwhile, donors and carbon investors compete to advance around 44 carbon sequestration (REDD+) projects that aim to mitigate climate change (REDD-I 2011).

To investigate trajectories of land acquisition and enclosure, this paper presents a historical analysis of four large-scale processes - those associated with rice, oil palm, Jatropha and carbon sequestration. Utilizing an actor-oriented approach, we explore the gap between plans and implementation. We advance four arguments. First, we question the degree to which 'land grabs' to meet the new 'green' and food security agendas really amount to a radical shift (e.g. GRAIN 2008). We argue against regarding these acquisitions and green projects as a single, coherent process that explains all manner of political-economic programs across a wide variety of settings. Rather, we argue for understanding current changes as a continuation or reintensification of ongoing disaggregated processes that are transforming 'outer island' spaces.

Second, we place current development plans in the context of a longer history. This longer historical context suggests that in many cases land acquisition plans and developmental scenarios will continue to be problematized, resisted and only partially realized as they bump into existing land uses, patterns of resource access, ecologies and rapid fluctuations in world commodity prices. Despite this history of failed large land schemes, as developmental narratives take up new global concerns they continue to legitimize large-scale land acquisitions in the same landscapes.

Third, we demonstrate that rural landscapes are marked by overlapping land claims, with competing indigenous and commercial smallholder land uses, or concession licenses and land use plans. In this sense, rural landscapes work as a palimpsest; a parchment where the effects of successive inscriptions and erasures 
associated with 'legal' and 'vernacular' processes can still be perceived. ${ }^{1}$ Vernacular land allocation and transaction processes are embedded in, and constrained by, locally specific political and market-based dynamics shaped by local understandings of identity and entitlement. ${ }^{2}$ While vernacular processes shaping land access and use can be decisive for land tenure in 'outer island Indonesia', formal land acquisition processes also remain critical. The dynamic interaction between these processes in each case affects the extent to which legalized acquisition processes lead to enduring land use changes.

Fourth, we argue that in many cases, regardless of legal provisions to the contrary, actors engage in land acquisition processes without the intention to use the land for the purpose mentioned in the plan or development license. ${ }^{3}$ Here we introduce the term 'virtual land grabbing' to characterize situations where, behind a façade of land acquisition for a stated purpose, there lies an agenda to appropriate subsidies, obtain bank loans using land permits as collateral, or speculate on future increases in land values. Our argument here points to the centrality of agendas of land control - projects which attempt to fix or consolidate forms of access to land-based wealth - as the key to understanding these phenomena (Peluso and Lund 2011). Distinguishing between 'real' and 'virtual land grabbing' requires a conceptual understanding of land acquisition as a process. In the case of 'virtual grabbing' only a few initial stages of land acquisition or enclosure processes occur; just sufficient to enable specific actors to pursue their own interests, which may or may not depend upon land use changes actually taking place.

The findings in this paper, based on our research in Indonesia, are highly significant for wider discussions of 'land grabbing'. First, the essay highlights the gap between plans as stated and schemes as implemented, showing that the mere proclamation of a land acquisition in accordance with global discourses on food, climate and energy crises can be sufficient to profit particular actors. Whether land schemes end up being developed or not, these acquisitions are important, given that they lead to the reworking of spatial plans and the issuing of land use permits. Moreover, working in a dialectical fashion, one 'failed' scheme can later end up as a 'success': by serving as the basis for the next set of schemes, the failed scheme plays a key part in the transformation of rural landscapes. In this sense, all land initiatives affect the ongoing construction of new patterns of ownership and control over nature in frontier areas, working to reconfigure or to entrench political power, and providing new opportunities for particular actors while marginalizing others. Our paper also highlights how an analysis in terms of virtual land acquisitions might help to explain the gaps between plans and implementation well beyond Indonesia.

\footnotetext{
${ }^{1}$ B. de Sousa Santos (2006) has used the palimpsest as a metaphor to characterize the intricate ways in which very different political and legal cultures and very different historical durations are inextricably intertwined in contemporary Mozambique.

${ }^{2}$ Here we use the term 'vernacular' to refer to socially embedded land allocation and transaction processes that do not conform to state regulations (cf. Chimhowu and Woodhouse 2007). Often there is a great deal of ambiguity regarding rights of access and compliance with rules during such processes, particularly as outcomes emerge through negotiations and disputes that involve the adaptation of customs and norms with powerful dominant interests and the impact of state licensing processes. For a discussion relevant to the Indonesian context, see McCarthy and Warren (2008).

${ }^{3}$ Land acquisition for purposes other than listed on the license or for speculative purposes is technically illegal under Indonesia's agrarian law, even though this is rarely enforced.
} 
Documentation on land grabs in other countries shows similar findings: land acquisition may not be as massive as suggested (Cotula et.al. 2011) ${ }^{4}$; the acquisition process is often decentralized with local actors playing a key role (Borras and Franco 2010, Deininger 2011); and planned projects are often only partially realized, or may be unlikely to succeed (Ness et al. 2010). Further, existing policies to avoid speculative uses - such as virtual land acquisitions - tend to be poorly implemented (Deininger 2011). Finally, this essay demonstrates that a broader consideration of the functions of land appropriations, including consideration of virtual land acquisitions, reveals the need to reconsider the impact and significance of 'land grabs' alongside the policies driving the expansion of corporate agriculture and 'green appropriations'.

This paper investigates trajectories of land acquisition and enclosure associated with development schemes, virtual land grabs and green acquisitions. It advances the four key arguments (outlined above) through an investigation of four large enclosure processes - the processes associated with rice, oil palm, Jatropha and forest sequestration. Before considering these four large enclosure processes in turn, the next section will discuss the centrality of state developmental rationalities that target the 'outer islands' for large land projects in Indonesia.

\section{Land acquisition and enclosure in Indonesia's outer islands}

To explore our case studies of large enclosure processes in Indonesia and to understand how this leads to our conclusions, we need to first discuss the history of projects to turn nature into economic or green resources. First, it is important to distinguish between the densely populated centre of the country, Java and Bali, and the islands that have customarily been referred to as 'the outer islands'. Java and Bali are the centers of intensive rice cultivation and are places where land tenure is relatively clearly defined. In contrast, Sumatra and Kalimantan are large islands with huge natural wealth, while the smaller islands of Nusa Tenggara Timur (NTT) are much drier and less fertile. Farmers in these 'outer islands' have combined various forms of swidden cultivation with cash crop production. In many situations these diverse livelihood approaches have been a 'rational economic and environmental choice for farmers' (Mertz et al. 2009, 259).

Over the longer term, macro-economic policies have focused on the use of forests and other land types in the 'outer islands' as catalysts for a structural transformation of the Indonesian economy and as sources of wealth accumulation for privileged politico-bureaucratic actors. We can distinguish a sequence of six transformational historical moments. ${ }^{6}$ First, there was an initial colonial phase focused on plantation development, centred on the plantation belt of North Sumatra. After the late 1960s, the rise of markets for timber and the emergence of technologies to exploit forests on a large-scale led to a focus on industrial logging. Next, the third stage focused on transforming 'forest' into food crop development areas, supported by a developmental discourse advocating self-sufficiency in rice. This project formed part of a state development strategy that involved a large-scale colonization project - the well-known transmigration program. Fourth, in the 1980s Indonesia began to transform logging and food estate areas in Sumatra and Kalimantan into oil palm and timber

\footnotetext{
${ }^{4}$ i.e. in terms of the GRAIN definition (GRAIN 2008).

${ }^{5}$ The inside-outside distinction is typical for a 'colonizer's model of the world' (Blaut 1993).

${ }^{6}$ See McCarthy (2012) which provides a more detailed discussion of this case.
} 
plantations, supported by a developmental discourse that advocated increasing nonoil export earnings and diversifying employment opportunities. Rising world crude oil prices and recognition of climate change have now precipitated a fifth stage. This has inspired the Indonesian government's policy for biofuel production in 2006, with Jatropha as a 'green champion' biofuel crop. Finally, as markets have emerged for the carbon locked up in forests and peat lands, the prospect has arisen of green appropriations for carbon sequestration. This paper analyzes the latter four processes in this sequence: rice for food security; oil palm for economic growth; Jatropha for green biofuel; and forest projects for carbon sequestration. In all four phases, a strong macro-policy narrative has legitimized large land acquisitions and state involvement. This paper uses these four large enclosure processes as case studies, to investigate trajectories of land acquisition and enclosure, and to advance our four key arguments.

Despite shifting policies over time, Indonesian governments have always supported transformative processes in landscapes. Successive state planners have conceived ambitious national projects to turn nature into economic resources, remolding landscapes as well as 'indigenous' land uses in desired ways (Scott 1998, McCarthy and Cramb 2009). Early colonial administrations appropriated land to facilitate the objective of developing Western enterprises. At this time land alienation was 'never a problem', as it was facilitated by colonial land law (Furnivall 1956, 337). After independence, state policies and laws continued to facilitate the allocation of land to plantations, and were reworked to support changing national development strategies. ${ }^{7}$ Advancements in technology and infrastructure enabled new resources to be accessed and used, creating new market opportunities and developing land markets (Wallace and Williamson 2006). This led to shifts in what is valuable and hence worth extracting or otherwise using (Schmink and Wood 1992). One land development project therefore gives way to another.

There are several reasons why Indonesian land development policies continue to target the outer islands. Firstly, the outer islands are perceived as having abundant uncultivated or 'marginal' land, and low population densities. Additionally, customary land rights in these areas tend not to be formally recognized; state institutions are weaker, and legal provisions governing land transaction tend to be poorly implemented. Many resource-rich areas in the outer islands retain a 'frontier' character: they are spaces in rapid transition, places where the state institutions and legal frameworks that might protect local inhabitants tend to be weak. More recently, even those outer islands that are relatively resource-poor have become the focus of plans for resource exploitation, with growing attention to 'marginal land'.

Indeed, the idea of 'empty', 'reserve' or 'marginal' land is central to the 'land grab' scenario set out in the literature, concepts that render areas classified as 'public land' available to appropriation. Typically this scenario is seen to involve the transition of 'reserve land' into production, along with the dispossession and the marginalization of existing landholders (Borras and Franco 2010, 9-10). The term 'marginal land' has various meanings in different disciplines (Tang et al. 2010, 113-114). For economists, land is marginal when the result of cost-benefit analysis is negative. Assessments also consider land marginal if it has poor quality, is remote, is arid, is infertile or lacks infrastructure (e.g. roads, electricity). Administrators can classify land as 'marginal' according to a number of categories: temporarily unused lands including land usually

${ }^{7}$ Such transformations have been relatively easy in forest areas. Following Indonesian law on forestry (41/1999), around 60 percent of the whole country's land is defined as state forest. 
cultivated, but that is purposely allowed to stay idle for more than one year (FAO 2006); 'meadows' used for herding livestock, and a rest category of 'other dry lands'. These technocrats' and administrators' categories feed into the imaginative projects that national planners develop for 'empty land', providing for the reshaping of both places and processes (Tsing 2005, 32). In short, the 'outer islands fit the profile not only of countries and landscapes which investors prefer to target, but also of locations for which large-scale land acquisitions will create the greatest risk of negative environmental and social outcomes' (Deininger 2011, 224).

Although land schemes in Indonesia often include commitments and promises regarding poverty alleviation or creation of rural employment, only in some cases is an actual improvement in smallholder livelihoods observed (McCarthy et al. 2012). Meanwhile, processes such as logging, large-scale oil palm and timber plantations, exclusionary conservation zoning, resettlement schemes and the emergence of cash crop commodity booms continue to significantly alter land uses. The impact on agrarian structures is seen clearly in successive agricultural censuses. Between 1983 and 2003 the Gini coefficient for land distribution in outer island Indonesia increased from 0.48 to 0.58 , indicating rapidly growing inequality in land ownership. In two 'outer island' provinces where researchers have carried out longitudinal surveys, South Sumatra and South Kalimantan, the percentages of households in the category of 'marginal farmers' (petani gurem), with landholdings considered too small to meet more than subsistence requirements, have increased from 9 percent to 20 percent and from 30 percent to 40 percent in each province respectively over 20 years (Lokollo et al. 2007). It is possible to read these changes as processes of deagrarianization, representing a diversification of livelihoods that are now less tied to the land. As Rigg (2006) argues, an agrarian crisis may have been averted through a shift in livelihoods to non-farm activities, and to economic activities beyond the village. To be sure, a dynamic class of entrepreneurial smallholders is emerging that, together with domestic investors, is deriving a lucrative livelihood from boom crops such as oil palm and cocoa (Hall 2011). As these emergent 'progressive farmers' buy up surrounding areas of land, their prosperity is linked with problems of agrarian differentiation and dispossession (Li 2002, McCarthy 2010, Hall 2011). And despite this new wealth, in areas distant from the markets provided by industrial and urban centres, opportunities for livelihood diversification remain limited. As many may only adjust through 'distress diversification' (Rigg 2006, 194), it is clear that very large numbers of rural poor remain. Indeed, analysts within Indonesia are worried about the shift in patterns of land ownership (Lokollo et al. 2007). In many remote agrarian settings outside Java and Bali, it remains less likely that those rendered marginal to the agrarian transition - or cycle of enclosures - will find better livelihoods on smaller areas of land, in the absence of supporting rural policy, or in rural markets with a low capacity to absorb labour ( $\mathrm{Li} 2010$ ). Civil society organizations that could support the marginalized are weak or absent in these areas.

The legal system in Indonesia may intend to protect the land rights of its citizens, including those who live in areas targeted for land acquisition. However, land rights are often insecure and contested. For example, state policies and laws that facilitate the allocation of lands to plantations have tended to be used in new ways to support national development strategies. Such transformations have been relatively easy in forest areas. Indonesian Forestry law classifies around 60 percent of the country's land as 'state forest,' over which the Ministry of Forestry asserts control. In resource-rich outer islands, this percentage is often even higher; in Central 
Kalimantan it is 82 percent (Afiff et al. 2010, 37). The Ministry of Forestry asserts the legal authority to allocate use of these areas, and to issue licenses to private companies for forest exploitation. Although Indonesian law does allow for state recognition of customary land rights, in practice there are many requirements. Most of all, this needs a strong political intention - an element that has tended to be missing. Consequently, such recognition is rarely accomplished (Bakker 2009). As a result, so-called 'state forests' include many cultivated fields and villages. For example, in the Central Kalimantan case discussed below, the land mapped as 'state forest' contains 187 villages with 350,000 inhabitants.

The process of decentralizing the state, which began in 2001, has complicated this further by increasing procedural and institutional complexity. This has exacerbated the lack of integrated institutional arrangements between key actors and agencies, without providing effective systems and structures to hold state-based actors accountable. Given the conflicts of interest between various state agencies, actors can utilize the inconsistencies regarding authority within the state legal system for their own ends, to advance particular interpretations on the status of land, and to contest particular allocations. Foreign companies wanting to access land face the challenge of identifying which state institutions to negotiate with to obtain legal permission to start operations. 'Fuzzy' land rights, in a context of overlapping tenurial regimes and unclear, complicated or conflicted procedures, mean that investors need to navigate elaborate networks of permits and recommendations to proceed. Yet, as Ho (2001) suggests, ambiguity in property relations can serve certain purposes. It allows communities, corporations and other actors to advance competing agendas and definitions, seeking justification in different areas of law. It also provides state based actors with maximum discretionary authority, allowing them to allocate development rights, to obtain political capital and opportunities for rent seeking. The downside is the 'high risk that the deliberate institutional ambiguity becomes an instrument in the violation of villagers' interests' (Ho 2001, 421). Where disputes are resolved by recourse to power or coercion, land conflicts remain extensive.

Decentralization of government authorities to the districts and provincial governments has exposed the reality that, behind the façade of policy narratives, the state functions as a cluster of institutions (Barker and Van Klinken 2009, 40-42). Politico-bureaucratic actors operate within a clientelist network that encompasses parties and corporations. In outer island Indonesia, actors thrive or flounder depending upon their control of rents derived from the resource sector. Following decentralization, District Heads are directly elected, and regional governments have a more formal role in the allocation of land use permits. These dynamics make regional governments responsive to locally powerful actors and interest groups, and those able to invest in a particular region, arguably dampening the influence of national policy agendas. These developments have influenced the proliferation of types of actors who are engaged in or benefit from large land schemes.

Taken together, these dynamics make it more difficult to locate a 'land grabbing' process that corresponds to a single, coherent or intelligible process of agrarian transition 'that assumes a linear pathway, and a predictable set of connections'

\footnotetext{
${ }^{8} \mathrm{~A}$ look at the 'Investment guide/ permit license mechanism' on the website of the Indonesia Investment Coordinating Board (BKKPM) gives an idea about the number of permits and recommendations required. Available from: http://www4.bkpm.go.id/contents/general/12/ permit-license-mechanism [Accessed 26 March 2012].
} 
(Li 2010, 69). What initially appears as an archetypal 'land grab' may turn out to exist within a virtual reality of state spatial planning and land development permits, or may work to a logic that differs from the formal policy intention.

We now turn to considering how the four key arguments are demonstrated within our four chosen case studies: the key food crop (rice); the key industrial cash crops (oil palm); biofuels (Jatropha); and finally forestry (carbon sequestration). We focus on the degree to which processes of land appropriation associated with each commodity are leading to dramatic transformations in land uses and property relations, and the question of who benefits in which way.

\section{Rice and food security}

We begin our discussion of the trajectories of land use acquisition and enclosure by considering the first of the four processes: large-scale enclosure processes motivated by the pursuit of food security or food self-sufficiency. Historically food self-sufficiency represents a long-term concern of Indonesian policy makers and has motivated national projects to grow rice in outer island areas. Rice, as Indonesia's main staple food, plays an important role in state efforts to maintain political stability, with policy makers reluctant to become overly dependent on fluctuating international markets (Timmer 1993). A food crisis will create complex political problems (Eifert et al. 2003), potentially creating massive social unrest that can be mobilized by political actors to topple a government. As an example, in the 1960s, 600 percent inflation and widespread food shortages contributed to the fall of the Sukarno regime. The next president, Suharto, responded by prioritizing self-sufficiency in rice production, including access to rice for the poor, and stability in rural areas. State policies included subsidies and market interventions involving BULOG, a state agency that set out to maintain adequate rice supplies at affordable prices. State revenues from the 1970s oil boom were used to improve agricultural infrastructure, to supply low-cost agricultural inputs and stimulate the introduction of high yielding rice varieties. ${ }^{9}$ The rice selfsufficiency policy appealed strongly to nationalist sentiments, and symbolized the Suharto regime's success in the mid-1980s. However, by the early 1990s national rice production could not keep up with increasing consumption.

As a solution, the Suharto government established a one million-ha rice cultivation project in Central Kalimantan, the 'mega-rice project'. ${ }^{10}$ Because the area consisted of undisturbed peat land, environmental groups argued that the project would have devastating ecological and social impacts. Suharto's authoritarian regime was not responsive to opposition criticism. The project is considered by some to have displayed much of the hubris of other examples of 'high modernism': a clear attempt to use centralized planning and rational engineering to remake a social and natural order to achieve a utopia (Scott 1998).

The project is now seen as a failure, due in large part to the unsuitability of the land for rice cultivation, and the devastating impacts on the environment and the livelihoods of the thousands of people within the project area. As in many earlier transmigration schemes in peat swamp areas, technocratic planners failed to learn the lessons offered by traditional farming techniques regarding choice of plants and

\footnotetext{
${ }^{9}$ For an overview of the Government's policy for increasing rice production see Hill (2000, 125-138).

${ }^{10}$ The actual size of the project area is approximately 1.4 million ha.
} 
cultivation methods on marginal soils. Engineering failures left upstream areas drought-stricken in the dry season, and flooded in the wet. This, together with forest fires that destroyed rattan gardens, ensured the collapse of the livelihoods of indigenous people over a wide area. At the same time, pest infestations led to failure of the agricultural efforts of many Javanese in-migrants, encouraging many to take up illegal logging or to return home after their period of government support ended (McCarthy 2012). The mega-rice project was not, however, a failure for all: it provided economic benefits through logging and the supply of heavy equipment (Suyanto et al. 2009, ii). In December 1999, after the fall of Suharto, the project was terminated. It stands as an example of how, even with extensive investment in food production, and even with the support of a powerful developmental state and major technological inputs, there is no guarantee of success.

The post-Suharto period saw several shifts in how state planners addressed the food security issue (Neilson and Arifin 2011). Under a more market-focused polity, after 2005 the Susilo Bambang Yudhoyono (SBY) government began attempting to secure 'food security' via imports. Indonesia has since become the fourth largest global rice importer, and this policy has been subject to harsh criticism and has become a political resource for government critics. In response to such criticism, and to the apparent challenges of accessing rice in the international market, since then agricultural policy makers have shifted back to supporting more intensive agricultural production on underutilized or 'idle land' in outer island Indonesia. ${ }^{11}$

In 2008, the Wall Street Journal reported that a project in Papua province was' the latest example of a new trend for developing countries to lease farmland to overseas investors in order to profit from rising global food prices'. ${ }^{12}$ In the project in question, the local District Head held the political ambition to develop Merauke into the center of rice production in eastern Indonesia (Ito et al. 2011, 3). He regarded food estate development as an opportunity to tap into corporate financing and advance the cause of establishing South Papua Province (Caroko et al. 2011, 15). In 2006, the national government supported the idea of food estate development, and designated Merauke as 'the national food basket' (Ito et al. 2011, 3), echoing Dutch colonial policies in 1939 in the same area (Manikmas 2010). Initially the plan was to establish the Merauke Integrated Rice Estate. In 2009, when newspapers reported that rice would be exported from Merauke to Saudi Arabia, the project's goals were adjusted and framed more explicitly in terms of 'food security', suggesting a throwback to mega-rice project style interventions (Media Indonesia 2011b). 'Energy security' became a second goal of the estate development, and in 2010 the Merauke Integrated Energy and Food Estate was launched. The Indonesian conglomerate Medco (which was also active in logging) had been offering financial backing and assistance to find foreign investors for the project. Medco proposed that at least a million ha in Merauke should be allocated for production of sugar cane, sorghum, rice, soybeans and maize, and strongly promoted this view to the president (Down to Earth 2008). As of 2011, there are also plans to open 2 million ha of new food estates in Sumatra and Kalimantan (Media Indonesia 2011c). Given the political importance of rice, however, the national government has faced political

\footnotetext{
${ }^{11}$ There are also efforts to improve production in rice producing areas (e.g. improved pest management), and other policies, including ensuring BULOG stockpiles are sufficient to avoid food shortages.

${ }^{12}$ Wall Street Journal $11 / 7 / 08$ cited in Down to Earth (2008).
} 
difficulties in attempting to obtain foreign investment to take control of these vast areas of land to produce rice for export. The food security issue posited limits to the 'land grab', by ensuring that food estates focus on domestic 'food security' issues. Moreover, as with the earlier case, these land acquisitions occur in more 'peripheral' areas unsuitable for intensive rice cultivation.

The political sensitivities raised by the project created other obstacles to implementation of the million ha food estate in Papua. Given the scarcity of labour in frontier areas, the mega-rice project would bring many migrants into Papua. Such immigration has often been associated with ethnic tension, given the difference in cultural practices between indigenous people and Javanese migrants. Some Papuans would view the practice of bringing Javanese labour into Papua as 'internal colonialization', and the project may well inflame separatist grievances. Taken together, these factors have made large investment in Papua more complex. In August 2011, the difficulties of freeing up the land, together with the objections of indigenous communities and a new District Head, culminated in, forcing the Minister of Agriculture to announce that food estates projects would be moved to East Kalimantan (Jakarta Globe 2011). With large areas now subject to land development licenses, the Merauke area is open for development, and rumours have continued to circulate that the area may still be developed for oil palm.

To sum up, then, contemporary large-scale acquisitions motivated by food security or food self-sufficiency agendas are congruent with earlier historical experiences. However, given the social, political and environmental constraints, there appears to be an inevitability to the partial realization or failure of many schemes. As in the other three processes to be discussed below, interactions between formal and vernacular processes of rural land development proved critical. Yet, even when acquisitions remained 'virtual', as in the one million-ha scheme, they have allowed actors to pursue interests (e.g. timber extraction) that did not require successful rice production. Further, the 'failed' acquisition process proved critical in the wholesale transformation of the landscape. In the ex-mega rice area in Central Kalimantan, the district government has issued plantation permits in an attempt to attract investors. The district could readily do this because the megarice project had already rezoned this deep peat forest area for agricultural production. By 2010, 23 oil palm plantation companies had been granted such licenses (Afiff et al. 2010). The next section examines enclosure processes associated with oil palm.

\section{Oil palm and export earnings}

We continue our discussion of trajectories of land use acquisition and enclosure by considering the development schemes and virtual land acquisitions associated with oil palm. In the 1980s, Indonesian state planners began to realise the developmental potential of oil palm. Since then, a developmental narrative has underpinned practices that have continued to attract investments and loans. As articulated by state officials, this narrative focuses on potential land as a lure to capital investment in a key global boom crop (McCarthy and Cramb 2009). Ever-rising prices in a global market have sustained an oil palm bubble that underpins this narrative. While there have been dips in global prices, these have quickly rebounded. After the 2008 price collapse, for example, prices increased by 15 percent by early 2011 
(Jakarta Post 2011). With global demand increasing, and with good crop yields, the expansive phase continued. As investors rely on the financial reality that oil palm production will deliver a high rate of return, government decision-makers have continued to develop exuberant oil palm development plans. ${ }^{13}$

Previously, under the New Order, various policies provided for smallholder out-grower schemes, which allowed for more indirect forms of control over production in smallholder areas. Under these contract schemes, smallholders would retain legal title and would be integrated into global supply chains through the contract form. A significant body of research demonstrates that, under favourable conditions, smallholders can obtain income from oil palm that is significantly higher in terms of return-to-labour than other options (Rist et al. 2010). Successfully integrated smallholders have experienced the positive aspects of insertion into highly productive, intensive agricultural systems. As a corollary of smallholder schemes - and the emergence of an independent smallholder sector the area cultivated by smallholders has grown by 2 million ha since 2000, and in 2009 accounted for approximately half of the total area under oil palm (USDA 2009). However, smallholders who have been left out, or included on less favourable terms, suffer as their agricultural products and rural wages fail to keep up with food price increases. Many are forced to sell land under livelihood crises (McCarthy 2010).

At the national level, planners consider very large areas of 'public land' to be available for plantations development. In 2004 the Directorate General of Plantation Production and Development estimated that 32 million ha were suitable for oil palm production. Indeed, planners had already rezoned large areas, previously designated as 'forest', for oil palm cultivation. Between 2000 and 2009, authorities allocated approximately 10 million ha of new land licenses to domestic and international investors (USDA 2009). The national daily Kompas stated that by 2010, district governments across the country had issued initial plantation licenses for over 26 million ha (Pontianak Post 2011). The national government had set a target of 15 million ha of oil palm by 2020, although by 2010 oil palm plantations encompassed 7.56 million ha (USDA 2010). Although actual cultivation is conducted at a fraction of the scale mentioned in initial plans and reports, the cultivation, processing and export of oil palm remain very significant activities. Every year, 33 oil palm companies manage to open around 300,000-400,000 new ha (Teoh 2010, Pontianak Post 2011).

In the context of the oil palm boom, the regional press illustrates the inflated, speculative nature of land acquisitions - or virtual land grabs - associated with this booming sector. During 2009-2010, West Kalimantan newspapers reported government estimates that up to six million ha of 'potential land' and 'critical land' in the province could be made available for oil palm. However, reports also noted plantation developers' lack of capacity to make use of this land: by late 2010, only 35 percent of the 1.5 million ha that the provincial government had zoned for oil palm had already been planted (Kapuas Post 2009). Government statistics revealed that companies were only planting 20,000 ha per year. Development permits became

\footnotetext{
${ }^{13}$ To date the expansion does not seem to be driven by biofuel markets - although many investments were put into biofuels just prior to 2008, the rapid decline in the oil price put the biofuel issue on ice for some time.
} 
objects of investment by speculators with little immediate prospect of plantation development over much of the land subject to development licenses.

Private and state companies had accumulated 'land banks' - land under various licenses that are currently inactive but are set aside for later development - estimated to extend to 6.5-7 million ha by 2008 (USDA 2010). Outside Sumatra, oil palm processing and transportation infrastructure has remained less developed. Consequently, licenses are much more valuable close to the infrastructure required for plantation development. ${ }^{14}$ Unused plantation licenses tend to work as 'development options' - or amount to 'a monopoly right to buy or use' - that allows for the possibility of either developing a plantation or selling on the opportunity. For entrepreneurs without the capital to actually invest in growing oil palm, initial investments for obtaining licenses tend to pay off because if the holder of the plantation permit is unable to proceed to the plantation stage, they can later trade the permit in a rising market and hence obtain a return on their initial investments. As new investors need to negotiate with those holding these relatively scarce 'development options', the investment is potentially very lucrative. This is particularly the case given the failure of state authorities to make use of provisions allowing for the cancellation of non-performing plantation concessions.

Large-scale foreign investment involving direct control over large areas of land plays a key role in most 'land grab' scenarios. Indeed, foreign investment remains significant, especially from other developing country sources. It was reported in 2011 that foreign investors own 25 percent of around two million ha of oil palm plantation area in Riau. Malaysian investors have also been carrying out intense plantation expansions in West Kalimantan, buying up around 50 percent of oil palm plantations in this province (Jakarta Post 2011).

Domestic and transnational players often play complementary roles (cf. Borras and Franco 2010). Rather than leaving themselves open to the accusation of engaging in 'land grabs' by taking up direct ownership of land under poor governance arrangements, foreign investors can be 'silent partners' of local firms in food and agro-fuel projects. To give just one example, in May 2008 it was reported that Bakrie Sumatera, a branch of the Bakrie conglomerate, was investing USD 260 million to double its plantation holdings, raising USD 80 million from an international equities consortium (Jakarta Post 2008).

However, integration into global production networks does not necessarily require direct control over production by investors. Large-scale palm oil buyers (e.g. Unilever) may sit at the downstream end, purchasing the undifferentiated product in bulk through globalized value chains. As buyers in decentralized global production networks, they can avoid some of the opprobrium associated with problems in the upstream sector where production takes place, reducing any negative impacts on their brand names through discontinuing purchases from problem companies and supporting certification schemes that provide for codes of conduct regarding land acquisition policies.

Clearly, oil palm expansion is inserted into a particular local politicaleconomic context that shapes outcomes. Following decentralization reforms, district officials hold key powers within networks involving local businessmen,

\footnotetext{
${ }^{14}$ This is a reason for local land owners' and license holders' lobby at district government to spend their budgets on infrastructure development.
} 
brokers, investors, local companies, local populations and large corporations. For district governments a failure to attract investors would be perceived as an inability to deliver the maximum development benefits. On the other hand, local governments who attract investors and issue large numbers of permits gain directly - from entitlements in oil palm schemes and through support for electoral programs in return for services rendered. Oil palm, in the words of one observer, has emerged as an 'elite business between investors and rogue officials (oknum) in the regional elite who possess control of the land' (Supriyanto, 2007). The low realization of land development compared with the total number of permits issued indicates the intensity of the practice of 'land division' and brokering of land permits by rogue regional officials (Pontianak Post 2009). In the absence of effective forms of accountability, too often customary and community leaders are involved in 'freeing up' land, in land sales manipulated by village heads and brokers.

The terms under which smallholders engage with oil palm have changed remarkably over the last decade. Government policies have consistently sought to liberalize investment requirements, for instance seeking to increase the length of agricultural concessions from 25 to 95 years, and allowing direct foreign investment in the sector. ${ }^{15}$ A new 'partnership' (kemitraan) policy privileged private sector partnerships with smallholders. Under this model, benefit and land sharing arrangements are to be negotiated directly with landowners in the field. Rather than providing 70 percent of an oil palm development to smallholders as under previous schemes, the core or 'nucleus' estate is only obliged to return 20 percent of the scheme land to villagers, retaining up to 80 percent of the land as its plantation estate. This amounts to a shift towards decentralized-localized community based negotiations that are easily manipulated. Large-scale violations continue despite codes of conduct and legal innovations that provide for elements of 'free, prior and informed consent'. This is because too often the local actors including community leaders and state officials - who play a mediating role in such processes have an underlying interest in ensuring that land acquisitions go ahead. ${ }^{16}$ As land- and benefit-sharing arrangements deteriorated under the new schemes, some might argue that this amounts to a type of reverse land reform or land grab. If plantation development that includes smallholders will only occur in accordance with policy that provides up to 80 percent of the development area to estates, this will exacerbate the increasingly salient problem of 'marginal farmers' who have landholdings deemed to be too small to meet subsistence requirements.

When the 'sweet promises' made by companies in the process of 'freeing up' land are not realized, large numbers of conflicts emerge. Too often farmers lose out at the point that customary or uncertified property rights are converted into staterecognized land tenure for concession licenses under district supervision. This is because land negotiations are left to local land owners and investors, leaving outcomes susceptible to the differences in power and knowledge between these two

\footnotetext{
${ }^{15}$ The 95-year lease provision of the 2007 Foreign Investment law was thrown out by the Constitutional Court as unconstitutional and in contravention of the Basic Agrarian Law in 2008.

${ }^{16}$ See Borras and Franco (2010), and for an analysis relevant to oil palm see McCarthy et al. (2012).
} 
parties. There are conflicts over land purchases and compensation processes deemed to be unjust, over the perceptions that plantations have failed to return smallholder 'plasma' entitlements, over the lack of extension and development assistance to smallholders, and over profit-sharing arrangements from 'fresh fruit bunches' at the farmer level that are deemed unjust (Borneo Tribune 2010; Colchester et al. 2006). NGOs claim that the level of conflict is growing during the era of decentralizedlocalized community based negotiations. ${ }^{17}$

In conclusion, the oil palm-related processes follow a characteristic pattern of fragmented, differentiated, and decentralized land acquisitions involving various coalitions of actors that parallels the other cases. Oil palm has emerged as the priority crop for many actors, particularly as it offers lucrative opportunities, not only from selling the oil. Despite the potent forces pushing real, large-scale transformations, we still find a significant gap between projects, plans and booster rhetoric and actual practices on the ground. In parallel with the pattern found in the other processes discussed in this paper, the oil palm boom also corresponds with an extraordinary number of 'virtual acquisitions' - speculatory activity involving the pocketing of permits. Critics have subjected palm oil palm expansion to strong criticism, particularly for its environmental impacts. ${ }^{18}$ Yet, in comparison with the other processes examined in this paper, oil palm has potentially the most significant implications for the livelihoods of local smallholders and agricultural labourers. Policy choices prefer large-scale, capital-intensive investments over more smallholder-focused initiatives that might provide for greater smallholder inclusion. In addition to oil palm, companies and governments do consider the potential of alternative crops more suited to 'marginal areas', and the next case discusses land acquisitions associated with one such crop.

\section{Jatropha and green biofuels}

We now turn to our third enclosure and land acquisition process: that associated with Jatropha. From 2003 onwards, a new set of large-scale land acquisitions focused on areas that planners had considered 'marginal' and thus economically uninteresting. These areas had yet to experience such large land projects. Yet, seen from a national perspective, this is a continuation of earlier policies to turn nature in the outer islands into economic resources. Rising world crude oil prices and attention to climate change inspired the Indonesian government's policy for biofuel production in 2006. This biofuel policy aimed at turning 'marginal' or 'degraded' areas into biofuel production zones. Interventions would need to develop areas with unsuited ecologies or otherwise poor infrastructure. Foreign investments in biofuel plantations would yield renewable energy, create employment and contribute to poverty alleviation. For example, projects could cultivate Jatropha, a crop deemed suited to 'marginal' dry land, in arid areas of the province Nusa Tenggara Timur (NTT). Unlike in Kalimantan or Papua, spatial planning processes mapped only a quarter of the land surface in this province as forest, and classified around 40 percent as unused or very extensively used land. In 2007

\footnotetext{
${ }^{17}$ According to one report, there were 660 conflicts in 2010 compared to 116 conflicts in 2009 (Pontianak Post 2011).

${ }^{18}$ For example, see the Greenpeace Kit-Kat TV commercial (Greenpeace 2010).
} 
provincial and national newspapers reported the first initiatives for large plantations in this province, which is one of the poorest areas of Indonesia. ${ }^{19}$

In the early 2000s, boosters claimed that Jatropha curcas was the ideal crop for producing energy from such marginal land without large inputs. Jongschaap et al. $(2007,5)$ listed 11 popular claims about the crop in 2007 , including that the crop reclaims marginal soils, is drought tolerant, has low nutrient requirements, provides high oil yields, and requires low labour inputs. However, those advancing these claims failed to utilize scientifically sound information.

Based on this advocacy, in 2007 the national daily Kompas announced international Jatropha investments in the Central Sumba district, on the island of Sumba in NTT. The new investments encompassed an area between 10,000 and 20,000 ha, and up to 100,000 ha in East Sumba (Biopact 2007). The provincial government website indicated that a total of $2,177,456$ ha would be available for Jatropha cultivation in the whole province (NTT Government 2009). The sheer size of these figures indicates the possibility of virtual land acquisitions. Checking against government statistics regarding 'empty land', it is apparent that in 2008, 42 percent of NTT remained unused (BPS-NTT 2010). This suggests there is ample land for agricultural enterprises in these districts. Given this, the question remains why these lands remained uncultivated. To realize plans for 20,000 ha of plantations in Central Sumba, developers would need to increase plantation areas by 400 percent, encompassing about a quarter of all the 'empty land'. As the land has poor infrastructure (or none at all), is undulating, has little water (no irrigation), and poor soil fertility, planners might consider it as 'marginal' to productive agriculture (GFA 2008). Additionally, these districts of NTT are sparsely populated. Consequently, very little labour is available locally. Large-scale plantations would also require well-managed logistics and marketing (Strydom 2006), a challenge in this remote frontier. The reality that these circumstances do not favour successful plantations further supports the suspicion that this might be a case of virtual land grabbing. However, if cultivation is not the real purpose, what could make such plans profitable?

The first answer in the case of Jatropha plans is subsidies. During the period 2005-2008, in Indonesia and many other countries (Ariza-Montobbio et al. 2010, Hunsberger 2010), government policy and legislation were interlinked with budgets and international subsidy flows driving Jatropha activities. The district Agricultural Service in West Sumba implemented a Jatropha introduction program, distributing seeds and inputs. Village agricultural extension workers explained cultivation methods for commercial purposes to farmers. The state owned enterprise PT Rajawali Nusantara Indonesia (PT RNI) implemented a demonstration plot close to the capital Waingapu in 2006-2007. PT RNI commissioned local producers in Sumba - including a member of the East Sumba District Parliament - to produce many thousands of Jatropha seedlings, a large percentage of which were never planted or died in the nursery (Vel 2008, Vel and Makambombu 2010). Actual cultivation and post-harvest activities, including trade, processing and transport, were apparently not included in the Ministry of Agriculture's projects.

\footnotetext{
${ }^{19}$ In 2009 National Statistics listed NTT as 31 st out of 33 in its ranking of provinces according to their Human Development Index (BPS 2010).
} 
Subsequent research revealed that large-scale land acquisitions for Jatropha had yet to eventuate. Apparently the actors involved in this Jatropha program never intended to grow Jatropha and produce biodiesel: they just harvested subsidies. The state had provided many Jatropha-related subsidies (Dillon et al. 2008, 36-43). These included interest rate subsidies, agribusiness development programs, infrastructure subsidies, tax reductions for biofuel-related investments, training programme support, and research and development budgets. Consequently, many Jatropharelated activities involved linking state agencies with each other in a subsidy chain. Seen from this perspective, newspaper reports regarding 100,000 ha of land acquisitions underpinned a discourse that supported budget grabbing among domestic actors and agencies.

The links between land acquisition plans, land permits and bank loans provide a second rationale for virtual land grabbing. This feature is not confined to Jatropha projects: it is part of a pattern of 'failing plantations' in Sumba. The website of the NTT Government (2009) provided two reasons for failing plantations. First, the rural population had traumatic past experiences with estate development in NTT. These projects had failed to bring economic benefits to farmers. Second, farmers wish to avoid investing in cultivating estate or cash crops that lack a stable market price. Indeed, in interviews, farmers in Central Sumba explained that they had planted many Jatropha trees in 2006 after hearing positive news regarding the plant's potential. Later they stopped cultivating when they found out there were no marketing channels or processing facilities. However, the reasons for non-implementation of announced large Jatropha schemes, or failing plantations, lie elsewhere. Other actors - entrepreneurs, state officials, and brokers - have used the plans for purposes other than cultivating crops. While they may have succeeded, 'plantation failure' has happened so often that we can see a pattern. $^{20}$

Sumba's wealth of 'empty lands' attracted many potential investors in agricultural projects. As in Central Kalimantan and Merauke, district governments in Sumba encouraged commercial agricultural development for district economic growth, rural employment, and district governments' tax income. Plantation initiatives over the decade to 2011 focused on Jatropha curcas, maize, cotton, sugarcane, cashew or sorghum. Field visits to the area where the plantations were planned revealed few operational activities. Interviews with the local population, NGOs and the district government services indicated the following pattern of experiences with plantation development in Sumba. First, a high government official introduces an idea for a new cash crop. There is a promising initial phase, and an Indonesian company responds by discussing potential plantation sites with the district officials. An international company or foundation gets involved as the investor (lender). Websites promote the idea and describe large-scale, long-term projects, creating high expectations. An official ceremony occurs, where companies and the district government sign a 'letter of intent' or 'a memorandum of understanding'. The local newspaper covers this signing ceremony and reports are posted on the internet.

\footnotetext{
${ }^{20}$ Since 2006 JacquelineVel has been observing the developments in large-scale commercial agriculture in Sumba, one of Indonesia's outer islands (Vel 2008, Vel and Makambombu 2010).
} 
Second, a phase of limited implementation follows. The district government issues a location permit for a much smaller area than the initial plans stated. This allows the company to start exploratory activities, and obliges the company to negotiate with local land owners about the terms for land use/acquisition, and to conduct an environmental assessment. The company sets up some minor activities: building one road, and one small warehouse; getting some equipment and making a fence and a sign board. Then the company tries to persuade local famers to collaborate with the plantation, particularly when this is a requirement for obtaining a bank loan. The plantation company employs a few local people as "permanent staff' and casual labourers to do seasonal work or to construct fences. Part of the land is cultivated with the crop for one or two seasons.

Third, we see the phase of acknowledging failure. Typically, after several years, activities end. Local informants describe instances where the company's management stated that the area was unsuitable after all, that the local population was uncooperative (and sometimes even burnt the plantation), or that the company was in financial trouble. There are always rumors about bankruptcy and plantation loans being used for other purposes. Finally the company disappears from the district scene.

Plantation failure does not reflect the willingness or capacity of farmers to develop cash crops. Farmers widely cultivate crops that have proven to be profitable. For example, cashews and candlenuts flourish as cash crops. At first, government and NGOs promoted these crops, but since 2009 smallholders have been producing most of the volume. With steady demand and prices, and a well-developed marketing channel, both crops have proved suited to the agronomic conditions of Sumba.

For biofuel crops, however, after the initial activities of promoting plans, exploring sites and applying for budgets, grants and subsidies, in many cases agricultural investments fail to materialize. Despite this, government officials welcome these land deals - even lobbying aggressively to ensure they occur (Kugelman 2009, 3). The deals may represent virtual land grabbing. In October 2011, we heard the pejorative term now used to refer to companies that specialize in virtual land grabbing: the label 'PT Akan', literally translated as 'Will Do Ltd', hints at the agenda behind the promise of future realization.

Consequently, the jatropha case clearly fits the wider pattern presented in this paper. Actual processes on the ground differ remarkably from the situation intimated by the land development narratives of project boosters. The jatropha phenomenon would seem to accord with the boom and bust cycle - high global prices and good prospects lead to an inflow of investment that is never realized. However, as developmental scenarios are consistently not achieved, another agenda becomes apparent: the use of permits to capture linked budgets and subsidies as well as the rents associated with investments. Thus, jatropha processes fit into our wider argument: as developmental narratives take up new global concerns, they continue to legitimize large-scale land acquisitions, leaving a heritage of failed large land schemes - in this case, as they remain spectral, there are limited impacts on the ground.

While foreign capital in part drives land acquisition for Jatropha plantations, the subsidies and bank loans are mostly from domestic sources. In the next section the role of international actors and capital is more apparent. Initiatives for reducing carbon emissions from deforestation in developing countries have necessitated a similar pattern of allocating large areas of land for green agendas. 


\section{Forests and carbon trading}

Finally, we now consider the fourth of our large enclosure processes: green acquisitions associated with carbon sequestration. The global initiative aimed at Reducing the Emissions from Deforestation and Forest Degradation, known as 'REDD,' amounts to another type of large-scale land allocation involving the injection of large capital investments into remote forest frontiers. The REDD scheme depends upon financial transfers from donor governments in highly industrialized countries to actors in developing countries where greenhouse gas (GHG) emissions from forest conversions are considerable. Among tropical countries, Indonesia ranks first and Brazil second as net GHG emitters, together contributing approximately 50 percent of global GHG emissions (Verchot and Petkova 2009). Under the initial proposal set out in the $13^{\text {th }}$ Conference of Parties under the United Nations Framework Convention on Climate Change in Bali in 2007, Indonesia would receive financial assistance to prevent further exploitation and degradation of its forests (PEACE 2007). Although the idea behind REDD is simple, the 'mechanism' is rather complicated. Local actors in a forest in Indonesia will only receive compensation payments for their REDD activities following a long and successful process of planning, calculation and negotiation. Any REDD project proposal requires approvals for the activities implemented. Further, it needs to document the size of the emission reduction, obtain a specified type of financing, and indicate how the benefits will be distributed (Parker et al. 2009, 18). This requires a variety of expertise and involves a multitude of actors. The scope of REDD has expanded to include carbon sequestration from conservation, sustainable management of forests, and enhancement of forest carbon stocks, now known as REDD+.

As in the cases discussed in the previous sections, there are huge claims regarding the areas that will be allocated for REDD + projects. Donors and implementing agencies are engaged in a rush to develop REDD+ projects, and although the precise number remains unclear, one report claimed that more than 60 REDD+ Demonstration Activities are currently being proposed by bilateral donors, NGOs, and private companies (World Bank 2011). For instance, in Central Kalimantan, five REDD+ projects are listed, encompassing 306,940 ha, and a number of private companies have submitted proposals for another 615,400 ha (Satuan Tugas REDD+ 2011). At least three of these projects are located in the former one million-ha rice project area discussed earlier.

The economic interests at stake are large. Donor commitment to Indonesia significantly increased after the G20 meeting in Pittsburg in 2009. Here President Susilo Bambang Yudhoyono announced the Government's commitment to reducing Indonesia's GHG emissions by 26 percent by 2020. Estimates of the size of donor countries' support for REDD+ schemes in Indonesia vary from USD 62 million (Satuan Tugas REDD+ 2011, 11) to USD 4.4 billion over the several years from 2011 (Brown and Peskett 2011, 12). The Norwegian government pledged USD 1 billion provided that Indonesia succeeds in reducing its emissions. As a first gesture, the Indonesian government issued a two-year forest moratorium in 2011 to freeze issuance of new forest exploitation permits to exploit natural primary forests and peat land. ${ }^{21}$

${ }^{21}$ This was agreed in a Letter of Intent between the Government of Indonesia and the Norwegian government. 
Four years after the Bali Conference, the institutional framework for implementing REDD + has yet to be established. It remains unclear which institution has the authority to prioritize a location, choose the type of REDD+ scheme to implement, and determine the requirements to be met before a proposal for a REDD+ project will gain government approval. As a consequence, it remains unclear how international funds will be spent. A variety of actors have emerged, each advancing their own REDD+ agendas. Foresters argue that in comparison to other land categories, peat areas store significant amounts of carbon. Indeed, degradation of Indonesian peat lands, and fire - for example caused by the mega-rice project discussed above - have caused major carbon emissions. Given that Indonesia has approximately half of the world's tropical peat lands (around 21 million ha), donors have focused on supporting REDD+ projects in outer island regions with large peatland ecosystems (DNPI 2011, 6).

Apart from environmental concerns, REDD+ also creates opportunities for forwarding other agendas. As in the case of Jatropha promotion, global discourses articulate with domestic dynamics and produce unexpected and officially unintended outcomes. To clarify this argument we focus on three types of actors: divisions of the Ministry of Forestry, plantation companies, and regional governments.

According to state law, the Ministry of Forestry has authority over nearly all forest land on which REDD+ activities will be applied. REDD+ provides a validation for further conservation-justified enclosures in the forestry estate, and for reasserting forestry department control over this vast area. By revaluing the carbon located in remote forests as a commodity, this also provides a rationale for land uses that compete with oil palm, timber plantation and mining enclosures.

The balance of power between different actors creates uncertainties. The Ministry of Forestry is organized in several divisions which compete to promote different types of forest activity. Powerful actors within the Ministry choose between policy options. Meanwhile agricultural and timber interests continue to influence decisions over forest land allocations. In 2010 the Minister of Forestry issued many mining concessions, while applications for community forestry land piled up. Oil palm plantation companies also lobby decision-makers strongly, in ways that risk corrupting the forest land allocation process. The oil palm businesses association advocates that oil palm should also be eligible for a carbon credit (Creagh 2010). Meanwhile regional (provincial and district) governments find REDD + a useful tool for underscoring their autonomy and claiming rights to make decisions regarding forest use. REDD+ connects these regional governments to international actors eager to bypass levels of bureaucracy. However, regional governments also weigh the benefits of REDD+ projects against the opportunity costs of allocating the land for other economic purposes. Where REDD+ options of combining REDD with oil palm plantations offer new revenue streams, this is very attractive to regional governments.

Competition, and overlapping responsibilities and roles between different state actors, contribute to poor policy coordination and contested property relations. These affect pilot projects, even after official project approval. For instance, in the case of PT. Rimba Raya Conservation, in 2009 the Ministry of Forestry issued a letter allowing the establishment of a carbon credit scheme, under a specific license, over approximately 90,000 ha of state forest. ${ }^{22}$ However, the regional government

${ }^{22}$ The license concerned an ecosystem restoration scheme (BPPHP Wilayah XII, 2010). 
had already issued a license to a private oil palm company over part of that same area. The regional government could have revoked the license, because the oil palm company had not yet commenced plantation activity, which is a legal basis for rescinding non-performing projects that leave land idle and unproductive. Moreover, the area is deep peat land that, according to law, should not be allocated to oil palm development. Instead of revoking the license, however, in 2011 the Ministry of Forestry chose to support the oil palm investment, subsequently reducing the carbon sequestration scheme to 40,000 ha of the forest land area (Fogarty 2011).

The REDD+ issue plays into longstanding conflicts over the system for allocating forest entitlements. REDD + frameworks are widely seen as favouring those with formalised property rights (Vatn and Angelsen 2009, 68). If implemented in ways that enable landowners to obtain formal property rights within the 'forest area', some argue that REDD+ may provide customary land owners with a means to maintain a foothold on their land vis-à-vis other policies and developments that threaten to displace them (Osborne 2011). But there is a risk that 'the formalisation of property rights may exclude the rural poor not only from access to REDD+ resources, but also from land in general' (Vatn and Angelsen 2009, 68). Further, carbon forestry restricts land uses in areas zoned for carbon sequestration. Villager participation in carbon markets may work to constrain access to important benefits that landowners may have enjoyed up until now (Osborne 2011). However, REDD+ also creates space for civil society and community actors to advocate recognizing indigenous rights in areas mapped within the forestry estate. The emerging coalition of foreign REDD+ actors - including the Norwegian government - and local people's representatives together with NGOs, is attempting to use REDD + as a means to support the interests of local populations, including access to land and fair compensation for land uses.

In summary, we can say that up to 2011, the land acquisition figures mentioned in reports on REDD + in Indonesia represent only the start of a long negotiation process. They do not yet correspond with real 'green appropriations'. In parallel with the other cases, REDD+ land claims remain 'virtual', until it becomes clear who decides on land allocations, exactly which activities will obtain REDD + funding, and how benefit-sharing arrangements will work. Once again, in large part the dynamic interaction between formal and vernacular processes will ultimately determine the extent to which legalized green acquisitions lead to enduring land use changes.

\section{Discussion}

The combined energy, climate and food crises require new remedies and provide new opportunities. As the solutions to climate-food and energy crises are relocated to frontier areas, they imply a new 'spatial fix' that entails geographical expansion and restructuring of developmental agendas (Harvey 2001, 24). Elaborate new macroeconomic and agribusiness agendas involve providing millions of hectares of agricultural and forest land for acquisition or enclosure, to make the most of these opportunities. New developmental discourses regarding green biofuels, carbon sequestration or food security provide the foundation for new land acquisitions where particular actors can connect to real places, promoting new land schemes. Despite the apparent novelty, however, the new acquisitions following these changes represent continuity with, rather than a clear break from, earlier patterns of land 
use change. Policy shifts have always corresponded with changes in technologies, market opportunities and state capacities in recognizable ways. Enduring policy rationalities continue to be applied to 'frontier' spaces. Planners conceive of 'outer island' places as spaces for the elaboration of ambitious national projects to remould both places and 'indigenous' land uses in desired ways (McCarthy and Cramb 2009), typically in response to newly identified problems and solutions, and technological preferences. The pursuit of these agendas depends upon control of land. Indeed, as in the colonial period, state legal formulations that prioritise property relations considered 'legal' and 'modern' over 'customary' and 'indigenous' relations remain the key to land acquisition. Yet vernacular processes are decisive for land tenure in 'outer island Indonesia'. Receiving formal development licenses from a state authority is actually just a step in the process of land acquisition. Subsequently, obtaining property rights in the field requires accommodating, compensating, co-opting or suppressing landowner claims though various local negotiation processes. This gap also corresponds to a fissure between normative developmental discourses describing what ought to be done, and how actual processes work out on the ground and determine who benefits.

As we have seen, only a fraction of land acquisitions lead to on-the-ground projects. While the reasons for the postponement or 'failure' of so many projects remain largely unexamined, we find a clear logic underlying these phenomena. In many cases, 'failed' projects may have been successful in other ways: 'virtual acquisitions' provide opportunities to appropriate subsidies, to obtain bank loans using land permits as collateral, or to speculate on future increases in land values.

Land mapping processes and concession licenses are never entirely 'dead letters': they provide the raw material for the next stage of land acquisitions. Too often 'failed' schemes can 'succeed' as they become the basis for the next set of schemes in the ongoing transformation of landscapes. Although the mega-rice project in Central Kalimantan failed to provide national (rice) food security, it paved the way for competing agendas - green acquisitions and oil palm projects.

Green biofuel and carbon sequestration discourses, and food security policy narratives, compete with high commodity prices generated in international vegetable oil markets to inflate the 'bubbles' that drive these land acquisition processes. In some cases, a setback proves temporary: as the 'bubble' fails to burst, it provokes further investment in land acquisitions. In other cases, falls in commodity markets and poor realization in the field appear to deflate the 'bubble' until a new chorus of 'spruikers' emerges. ${ }^{23}$ The fact that these rival investment agendas may compete in the same landscape only works to speed up the process. As a new opportunity for investment emerges, demand for particular types of land rises. As the bubble inflates, actors chase particular sorts of land development licenses, including actors who lack the capital to implement a project. Once land development licenses become an object of investment, any new actor proposing to invest needs to buy out the existing licence. In such cases, it is easy to misread the large numbers of licenses and project schemes: virtual becomes real.

In comparing the dynamics shaping the different enclosure processes examined here, we find it important to distinguish between differences in timing, scale, mode of

\footnotetext{
${ }^{23} \mathrm{~A}$ spruiker is 'someone who toots their own horn', a tout, or 'a person standing outside a place of business trying to persuade patrons to enter, or vigorously trying to persuade customers to purchase their wares' (http://en.wiktionary.org/wiki/spruiker).
} 
transformation and outcome, as they relate to the characteristics of each commodity. In the first case considered here, the one million-ha mega-rice project in Central Kalimantan, President Suharto pushed a scheme to achieve national rice selfsufficiency, applying all the capacities available to the developmental state. However, the plan made little ecological sense. Weak and failing implementation - together with other rent-seeking agendas - left a wide space between intentions and plans and field realities. Over a decade later, after the demise of Indonesia's developmental state, a similar food estate plan took shape in Papua. In accord with policy settings that now privilege decentralization and public-private partnerships, the regional government and the private sector drove the project. In the planned Merauke food estate case, the politically charged food security issue limited the prospects for a large scheme for rice production. Any new food estate plans needed to be framed in terms of domestic 'food security' issues, as projects legitimized to secure the domestic food supply rather than food for export. Land tenure conflicts in Papua and national political resistance forced the plan to be abandoned.

Oil palm development is also associated with large-scale speculatory land acquisitions. Oil palm cultivation is very real and profitable, and large-scale land use changes often ensue. With global demand booming, state planners announced ambitious developmental targets. As the bubble has inflated, entrepreneurs have chased land development licenses, including many who lack the capital to implement a project. Virtual land acquisitions associated with oil palm are now very extensive: by 2010, 26 million ha of oil palm plantation licenses had been issued, despite a capacity only to plant around 500,000 ha of oil palm each year.

In the case of jatropha, land permits work as a means to access subsidies. 'Green', environmental and poverty alleviation arguments in international discourse lent support to agendas tied to this crop between 2003 and 2009. The Indonesian government promoted Jatropha cultivation, and allocated a considerable budget for research and implementation by the agricultural service. Despite poor results in the field, optimistic information about the crop's potential, combined with its superficial yet well-marketed 'green' image, continues to create new international investment flows. Virtual land grabbing in the case of jatropha often amounts to 'budget grabbing': successfully appropriating government budgets and subsidies. It requires a continuous flow of supporting information on corresponding land acquisitions. In fact, land permits are collateral for bank loans, even before there is any activity in the field. Then, whenever a plantation company allocates the loan for other purposes, and fails to implement its proposed agribusiness activities, the land acquisition remains virtual.

In the years to 2012, the REDD+ boom has been driven by significant donor funds and subsidies. As policy frameworks, the shape of future carbon markets, and tenurial issues remain unresolved, these pilot projects remain virtual (forest) land acquisitions rather than restored or conserved forests. Given the competing demand for land for agricultural expansion, it remains unclear how REDD+ projects alone will halt the expansion of oil palm or avoid displacing plantation development into forests outside REDD+ project areas (Poffenberger and Smith-Hanssen 2009, 2).

\section{Conclusion}

In comparing across the four processes of land acquisition and enclosure, we find that current changes continue well-established historical trajectories of 
land transformation. As we have repeatedly seen, there is a clear logic underlying the pattern of partial realization or 'failure' of many large-scale schemes. Further, we stress the importance of interactions between formal and vernacular processes in determining the outcomes of rural land development. Finally, we argue that many apparent cases of 'land grabs' are better understood as virtual land acquisitions.

With respect to the second of these four arguments, we see dynamics working against large-scale land acquisitions that offer interesting contrasts with the forces Polyanyi found as acting to slow down or even reverse the extension of market relations. In his classic discussion, Polanyi (1944) described the emergence of protective counter-movements that materialize as social actors respond to the deleterious impact of market relations. In the Indonesian case, we have yet to see effective counter-moves to protect local sources of livelihood and to de-commodify land. In many oil palm cases, rather than cessation of commercial smallholder farming per se, smallholders tend to focus on demanding more effective inclusion in the new market opportunities. Nonetheless, developmental scenarios often continue to be problematised, resisted and only partially realised as schemes confront the difficulty of vernacular land tenure processes that lead to difficult land negotiations and extensive land conflicts. Ecologies and commodity price fluctuations impede large-scale plans - whether they be buying up large areas for corporate agriculture for food production or enclosing huge areas for other schemes. These, together with the inchoate reactions of various actors cumulatively - albeit partially - slow land acquisition processes.

Along with other researchers, we find that in the majority of cases domestic investors are more important than foreign ones (Deininger 2011,218). Developments tend to occur within decentralized networks that involve national companies along with domestic and international investors in transformative processes. This is because access to land involves complex land transactions with farmers, state officials, brokers and agro-industrial enterprises working at various scales. And even in the case of REDD+ schemes that more clearly involve international actors, still domestic actors with their own agendas will determine the success of implementation and the distribution of benefits. The strength of actors in the global production networks of crops (such as those considered here) requires knowledge and information. Especially in the case of REDD + the procedures and processes for accessing subsidies are very complicated, increasing the power of legal experts and brokers. Finally, the ultimate question concerns the impact of large-scale land acquisitions - including virtual ones - on the livelihoods of local smallholders and agricultural labourers. Policies and schemes - whether they are realized or not demonstrate a bias towards development models that are large-scale and involve significant capital investments, rather than privileging labour-intensive initiatives that support smallholder inclusion (Cotula and Vermeulen 2010). This involves the alienation of large areas of land. As several analysts have argued, access to land 'is strongly related to poverty and inequality' (Borras et al. 2007, 1). While livelihoods are becoming less tied to the land across Indonesia, this trend is less pronounced in outer island Indonesia (Lokollo et al. 2007). In the absence of effective safety nets, finding better livelihoods on smaller areas of land is difficult. Further, the pursuit of improved livelihood occurs in the absence of supporting rural policy, and in rural markets with a low capacity to absorb labour. In the meantime, land can serve as a primary source of social security for the rural poor, providing a basic means of livelihood, making food more available, and providing a buffer against 
external shocks. Indeed, Indonesian research has found that 'there is a strong correlation between agricultural land ownership and the magnitude of poverty': 'the less land owned the higher the incidence and degree of poverty' (Rusastra et al. 2008, 30). From this perspective, large-scale land acquisition patterns are associated with 'disruptive shifts in land rights and increased land concentration' (UN 2010, 5), a trajectory that does not favour the poor. Even if acquisitions are virtual, there are opportunity costs: if there is little activity in the field, local people may neither work for the plantation company nor obtain secure access to the land concerned.

Advocates for alternative policies targeted at securing livelihoods for smallholders need to be aware of the dynamics described here. Classic advocacy strategies tend to target land reform. Whether the vexed question of land reform can ever be resolved, ${ }^{24}$ an associated issue is of more pressing concern to local livelihoods: state policy supports large-scale acquisitions linked with international investment associated with commodity booms, together with green agendas, while insufficiently addressing the structural constraints that limit smallholder production. Advocates for alternative policies might strongly question arrangements that seek to attract large-scale investors with the offer of 'free' land or forest. Given the increasing value of land, the state is arguably in a much stronger bargaining position to set the terms of investment in agrarian and forested landscapes in ways that support smallholder inclusion. However, as the four cases in this paper suggest, Indonesia has yet to see the political conditions that might ensure that state-based actors pursue policies that explicitly privilege the interests of local smallholders and agricultural labourers.

\section{References}

Afiff, S.A., Kussaritano and A. Merridian. 2010. Kajian Konflik Tenurial dan Analisis Para Pihak (stakeholder analysis) di Kawasan Pengembangan Lahan Gambut di Provinsi Kalimantan Tengah. Jakarta: Kemitaan/Partnership for Governance Reform.

Akram-Lodhi, A.H. and C. Kay. 2009. The agrarian question: peasants and rural change. In: H. Akram-Lodhi and C. Kay, eds. Peasants and globalization: political economy, rural transformation and the agrarian question. London and New York: Routledge, pp. 3-34.

Ariza-Montobbio, P., S. Lele, G. Kallis and J. Martinez-Alier. 2010. The political ecology of Jatropha plantations for biodiesel in Tamil Nadu, India. Journal of Peasant Studies, 37(4), 875-897.

Bakker, L.G.H. 2009. Who owns the land? Looking for law and power in Reformasi East Kalimantan. Nijmegen: Radboud Universiteit Nijmegen.

Barker, J. and G. van Klinken. 2009. 'Reflections on the state in Indonesia'. In: G. van Klinken and J. Barker, eds. State of authority: the state in society in Indonesia. Ithaca, NY: Cornell University Press, [Southeast Asia Program Studies 50], pp. 17-45.

Biopact. 2007. Israel's Merhav Group considers $\$ 700$ million biofuel investment in East Nusa Tenggara, Indonesia. Heverlee (Belgium): Biopact. Available from: http://news.monga bay.com/bioenergy/2007/09/israels-merhav-group-considers-700.html. [Accessed 12 January 2012].

Blaut, J. 1993. The colonizer's model of the world: geographical diffusion and eurocentric history. New York and London: The Guilford Press.

Borneo Tribune. 2010. Optimalisasi hasil produksi low productivity. Borneo Tribune, 30 March.

Borras, S.M. and J. Franco. 2010. Towards a broader view of the politics of global land grab: rethinking land issues, reframing resistance. ICAS Working Paper Series No. 001. Netherlands: Initiatives in Critical Agrarian Studies; Land Deal Politics Initiative and Transnational Institute.

${ }^{24}$ For an overview of the difficulties facing land reform, see Lucas and Warren (2003) and McCarthy and Moeliano (2012). 
Borras, J.S., C. Kay and A. Akram Lodhi. 2007. Agrarian reform and rural development: historical overview and current issues. ISS/UNDP Land, Poverty and Public Action Policy Paper No. 1. New York, NY: United Nations Development Programme.

BPPHP Wilayah XII. 2010. Statistik Kehutanan Kalimantan Tengah 2010. Palangkaraya: Balai Pemantauan dan Pemanfaatan Hutan Produksi (BPPHP) Wilayah XII.

BPS. 2010. Human Development Index (HDI) by Province and National 1996-2009. Jakarta: Badan Pusat Statistik Republik Indonesia. Available from: http://dds.bps.go.id/eng/ tab_sub/view.php?tabel $=1 \&$ daftar $=1 \&$ id_subyek $=26 \&$ notab $=2$ [Accessed 12 January $201 \overline{2}]$.

BPS-NTT. 2010. NTT in Figures 2009. Kupang: Badan Pusat Statitik Propinsi Nusa Tenggara Timur (Central Statistics Agency Province NTT).

Brown, J. and L. Peskett. 2011. Climate finance in Indonesia: lesson for the future of public finance for climate change mitigation. Overseas Development Institute (ODI) Working Paper No. 11. February 2011. http://www.edc2020.eu/fileadmin/publications/EDC_2020__Working_Paper_No_11_-_Climate_Finance_in_Indonesia.pdf [Accessed 12 January 2012].

Caroko, W., H. Komarudin, $\bar{K}$. Obidzinski and $\bar{P}$. Gunarso, P. 2011. Policy and institutional frameworks for the development of palm oil-based biodiesel in Indonesia. Working Paper 62. Bogor: Center for International Forestry Research (CIFOR). Available from: http:// www.cifor.org/publications/pdf_files/WPapers/WP62Komarudin.pdf [Accessed 26 March 2012].

Chimhowu, A. and P. Woodhouse. 2007. Vernacular land markets and rural poverty: reflections on land transactions in Svosve Communal Area, Zimbabwe. Manchester, UK: IDPM, University of Manchester. Available from: www.povertyfrontiers.org/ [Accessed 12 January 2012].

Creagh, S. 2010. Indonesia may let oil palm growers collect CO2 Credits. Reuters, 9 Aug. http://www.orangutans.com.au/Orangutans-Survival-Information/Indonesia-may-let-palmoil-growers-collect-CO2-credits.aspx [Accessed 12 January 2012].

Colchester, M., N. Jiwan, Andiko, M. Sirait, A. Y. Firdaus, A. Surambo and H. Pane. 2006. Promised land. Palm oil and land acquisition in Indonesia: Implications for local communities and indigenous peoples. Bogor: FPP, Sawit Watch, ICRAF, HuMa.

Cotula, L. and S. Vermeulen. 2010. Over the heads of local people: consultation, consent, and recompense in large-scale land deals for biofuels projects in Africa. Journal of Peasant Studies, 37(4), 899-916.

Cotula, L., S. Vermeulen, P. Mathieu and C. Toulmin. 2011. Agricultural investment and international land deals: Evidence from a multi-country study in Africa. Food Security, 3(Supplement 1), 99-113.

Deininger, K. 2011. Challenges posed by the new wave of farmland investment. Journal of Peasant Studies, 38(2), 217-247.

De Schutter, O. 2011. How not to think of land-grabbing: three critiques of large-scale investments in farmland. Journal of Peasant Studies, 38(2), 249-79.

Dillon, H.S., T. Laan and H.S. Dillon. 2008. Biofuels at what cost? Government support for biodiesel and ethanol in Indonesia. Geneva: Report for Global Subsidies Initiative of the International Institute for Sustainable Development. Available from: http://www.iisd.org/ pdf/2008/indonesia_biofuels.pdf [Accessed 12 January 2012].

DNPI. 2011. DNPI Green Review on REDD+. Jakarta: Dewan Nasional Perubahan Iklim.

Down to Earth. 2008. Merauke mega-project raises food fears. Down to Earth No.78, August 2008. http://www.downtoearth-indonesia.org/old-site/78dpad.htm [Accessed on 4 October 2011].

Eifert, B., A. Gelb and N.B. Tallroth. 2003. Managing oil wealth. The political economy of oil-exporting countries - why some of them have done so poorly. Finance and Development, 40(1), 1-11.Available from: http://faculty.nps.edu/relooney/3040_c139.pdf [Accessed 12 January 2012].

FAO (Food and Agriculture Organization of the United Nations). 2006. Metadata for agricultural statistics in Indonesia. Rome. Available from: http://www.faorap-apcas.org/ rdes/PPT/indonesia_metadata.pdf [Accessed 12 January 2012].

Fogarty, D. 2011. Special Report: how Indonesia hurt its own climate change project. Reuters, August 16. Available from: http://www.reuters.com/article/2011/08/16/us-indonesia-carbonidUSTRE77F0IK20110816 [Accessed 26 March 2012]. 
Furnivall, J.S. 1956. Colonial policy and practice. A comparative study of Burma and Netherlands India. New York: University Press.

GFA Consulting. 2008. Feasibility study: development of Jatropha curcas oil for bioenergy in rural areas - Indonesia. Jakarta, Indonesia: A consultancy report for the Ministry of Agriculture.

GRAIN. 2008. Seized! the 2008 land grab for food and financial security. GRAIN. Available from: www.grain.org/go/landgrab [Accessed 12 January 2012].

Greenpeace. 2010. Ask Nestlé to give rainforests a break. Amsterdam: Greenpeace International. Available from: http://www.greenpeace.org/international/en/campaigns/ climate-change/kitkat/ [Accessed 4 January 2012].

Hall, D. 2011. Land grabs, land control, and Southeast Asian crop booms. Journal of Peasant Studies, 38(4), 837-57.

Harvey, D. 2001. Globalization and the 'spatial fix'. Geographische Revue, 2, 23-30.

Hill, H. 2000. The Indonesian Economy. (Second edition) Cambridge: Cambridge University Press.

Ho, P. 2001. Who owns China's land? Policies, property rights and deliberate institutional ambiguity. The China Quarterly, 166, 394-421.

Hunsberger, C. 2010. The politics of Jatropha-based biofuels in Kenya: Convergence and divergence among NGOs, donors, government officials and farmers. Journal of Peasant Studies, 37(4), 939-62.

I-Newswire. 2010. Launched: Jatropha biofuel project in Indonesia. Bergenfield: I-Newswire. Available from: http:/www.i-newswire.com/launched-Jatropha-biofuel-project/31528 [Accessed 12 January 2012].

Ito, T., N.F. Rachman and L.A. Savitri. 2011. Naturalizing land dispossession: A policy discourse analysis of the Merauke integrated food and energy estate. Paper presented at the International Conference on Global Land Grabbing, Brighton, UK, 6-8 April.

Jakarta Globe. 2010. Indonesian forestry plan undermines carbon cuts. Jakarta Globe Greenomics, 1 November. http://www.thejakartaglobe.com/nvironment/indonesianforestry-plan-undermines-carbon-cuts-greenomics/352122 [Accessed 12 January 2012].

Jakarta Globe. 2011. Faisal Maliki Baskoro: Indonesia turns back on Papua food bowl plan. Jakarta Globe, 15 July. http://www.thejakartaglobe.com/business/indonesia-turns-backon-papua-food-bowl-plan/459493 [Accessed 12 January 2012].

Jakarta Post. 2008. Bakrie to expand oil palm plantation area. Jakarta Post, 14 May. http:// www.thejakarthttp://www.thejakartapost.com/news/2008/05/14/bakrie-expand-oil-palmplantation-area.html [Accessed 12 January 2012].

Jakarta Post. 2011. Riau to restrict land domination by foreign investors. Jakarta Post, 18 January. http://www.thejakarthttp://www.thejakahttp://www.thejakartapost.com/news/ 2011/01/18/riau-restrict-land-domination-foreign-investors.html [Accessed 12 January 2012].

Jongschaap, R.E.E., W.J. Corre, P.S. Bindraban and W.A. Brandenburg. 2007. Claims and facts on Jatropha curcas L. Global Jatropha curcas evaluation, breeding and propagation programme. Report 158. Laren, The Netherlands: Plant Research International BV, Wageningen and Stichting Het Groene Woudt.

Kapuas Post. 2009. Dari 1.5 Juta Ha Untuk Kelapa Sawit. Kapuas Post, 18 August. http:// www.thejakarthttp://www.thejakahttp://www.thejakartapost.chttp://kapuaspostlandak.blog spot.com.au/2009/08/dari-15-juta-ha-lahan-untuk-kelapa.html [Accessed 12 January 2012].

Kompas. 2007. Swedia tanam jarak investasi Rp 1 triliun, lahan tetap milik warga. Kompas 17/8/2007 http://tkimia.21.forumer.com/a/swedia-tanam-jarak-investasi-rp-1-triliun_post 746.html [Accessed 12 January 2012].

Kompas. 2011. Konflik di Perkebunan Sawit Meningkat Konflik Agraria. Kompas, 5 January. http://www.walhi.or.id/id/ruang-media/walhi-di-media/berita-perkebunan-besar/ 192-konflik-agraria-konflik-di-perkebunan-sawit-meningkat.html [Accessed 12 January 2012].

Kugelman, M. 2009. Introduction. In: M. Kugelman and S. Levenstein, eds. Land Grab? The race for the world's farmland. Washington, DC: Woodrow Wilson International Center for Scholars.

Li, T.M. 2002. Local histories, global markets: cocoa and class in Upland Sulawesi. Development and Change, 33(3), 415-437. 
Li, T.M. 2010. To make live or let die? Rural dispossession and the protection of surplus populations. Antipode, 41(1), 66-93.

Lokollo, E.M. et al., 2007. Dinamika Sosial Ekonomi Pedesaan: Analisis Perbandingan Antar Sensus Pertanian. Bogor: Pusat Analysis Sosial Eknomi dan Kebijakan Pertanian Badan Penelitian dan Pengembangan Pertanian Departmen Pertanian.

Lucas, A. and C. Warren. 2003. The State, the people, and their mediators: the struggle over agrarian law reform in post-New Order Indonesia. Indonesia, 76, 87-126.

Manikmas, M.O.A. 2010. Merauke Integrated Rice Estate: the awakening of food security and food sovereignty for the eastern part of Indonesia. Analisis Kebijakan Pertanian, 8(4), $323-338$.

McCarthy, J. and R. Cramb. 2009. Policy narratives, landholder engagement, and oil palm expansion on the Malaysian and Indonesian frontiers. The Geographical Journal, 175(2), $112-123$.

McCarthy, J.F. 2010. Processes of inclusion and adverse incorporation: oil palm and agrarian change in Sumatra, Indonesia. Journal of Peasant Studies, 37(4), 821-850.

McCarthy, J.F. 2012. Tenure and transformation in Central Kalimantan: the 'Million Hectare' Project. In: A. Lucas and C. Warren, eds. Land for the people: state policy and agrarian conflicts in Indonesia. Ohio: University Press, (in press).

McCarthy, J.F., P. Gillespie and Z. Zen. 2012. Swimming upstream: Local Indonesian production networks in 'globalized' palm oil production. World Development, 40(3), $555-569$.

McCarthy, J.F. and M. Moeliano. 2012. The post-authoritarian politics of agrarian and forest reform in Indonesia. In: R. Robison, ed. Routledge handbook of Southeast Asian politics. Routledge.

McCarthy, J.F. and C. Warren (2008). Communities, environments and local governance in Reform Era Indonesia. Community, Environment and Local Governance in Indonesia. C. Warren and J.F. McCarthy. Oxon, Routledge: 1-26.

Media Indonesia. 2011a. Food Estate di Merauke akan Dipercepat Jakarta. Media Indonesia, 8 Jan. http://tkimia.21.forumer.com/a/swedia-tanam-http://www.mediaindonesia.com/ $\mathrm{read} / 2011 / 01 / 01 / 193708 / 4 / 2 /$ Proyek-Food-Estate-Merauke-akan-Dipercepat [Accessed 12 January 2012].

Media Indonesia. 2011b. Pemerintah Tangani Infrastruktur Food Estate. Media Indonesia, 25 Jan.

Media Indonesia. 2011c. Food Estate di Merauke akan Dipercepat. Media Indonesia, 8 Jan. http://www.mediaindonesia.com/read/2011/01/01/193708/4/2/Proyek-Food-EstateMerauke-akan-Dipercepat- [Accessed 12 January 2012].

Mertz, O. et al., 2009. Swidden change in Southeast Asia: understanding causes and consequences. Human Ecology, 37, 259-264.

Neilson, J. and B. Arifin. 2011. Food security and the de-agrarianisation of the Indonesian economy. In: C. Rosin, P. Stock and H. Campbell, eds. Food systems failure. The global food crisis and the future of agriculture. London: Routledge.

Ness, B. et al., 2010. The African land grab: creating equitable governance strategies through codes-of-conduct and certification schemes. 2009 Amsterdam Conference on the Human Dimensions of Global Environmental Change. Amsterdam, 2-4. December. Available from: http://www.earthsystemgovernance.org/ac2009/papers/AC2009-0294.pdf [Accessed 4 January 2012].

NTT Government. 2009. Jarak Pagar (Jatropha). Kupang: Provincial Government of Nusa Tenggara Timur. Available from: http://www.nttprov.go.id/ntt_09/index.php?hal= potjarak [Accessed 12 January 2012].

Obidzinski, K. and A. Dermawan. 2010. Smallholder timber plantation development in Indonesia: what is preventing progress? International Forestry Review, 12(4), 339-48.

Osborne, T.M. 2011. Carbon forestry and agrarian change: access and land control in a Mexican rainforest. Journal of Peasant Studies, 38(4), 859-83.

Oxfam, 2011. Land and power. The growing scandal surrounding the new wave of investments in land. 151 Oxfam Briefing Paper 22 September 2011. Available from: www.oxfam.org/ grow [Accessed 30 January 2012].

Parker, C. et al., 2009. The Little REDD+ Book. Oxford: The Global Canope Foundation. 
PEACE (PT Pelangi Energi Abadi Citra Enviro, World Bank). 2007. Indonesia and climate change: current status and policies. World Bank Report. Available from: http://apo.org. $\mathrm{au} / ? \mathrm{q}=$ node $/ 2517$ [Accessed 2 February 2012].

Peluso, N.L. and C. Lund. 2011. New frontiers of land control: introduction. Journal of Peasant Studies, 38(4), 667-681.

Poffenberger, M. and K. Smith-Hanssen. 2009. Forest communities and REDD climate initiatives, Honolulu: East-West Center. Asia Pacific Issues, No. 91. http://www.community forestryinternational.org/publications/articles/Forest_Communities_and_REDD-EWC-2009. pdf [Accessed 12 January 2012].

Polanyi, K. 1944. The great transformation. New York: Farrar and Reinhart.

Pontianak Post. 2009. Adalah buah isapan jempol belaka. Supriyanto, 7 April.

Pontianak Post. 2011. Di Balik Nikmatnya Minyak Sawit. Pontianak Post, 19 January.

REDD-I. 2011. Proyek percontohan. Jakarta: Ministry of Forestry (FORDA). Available from: http://www.redd-indonesia.org/index.php?option=com_content\&view=article\&id= 205\&Itemid $=57$ [Accessed 12 January 2012].

Rigg, J. 2006. Land, farming, livelihoods, and poverty: Rethinking the links in the rural South. World Development, 34(1), 180-202.

Rist, L., L. Feintrenie and P. Levang. 2010. The livelihood impacts of oil palm: Smallholders in Indonesia. Biodiversity and Conservation, 19(4), 1009-1024.

Rusastra, I.W., T.A. Napitupulu,and R. Bourgeois. 2008. The impact of support for imports on food security in Indonesia. CAPSA Working Paper No. 101. Economic and Social Commision for Asia and the Pacific. New York: United Nations.

Santos, B. de Sousa. 2006. The heterogeneous state and legal pluralism in Mozambique. Law and Society Review, 40, 39-75.

Satuan Tugas REDD+. 2011. Strategi Nasional REDD+. A draft report prepared by the Task Force for the development of REDD+ Institution in Indonesia. Bappenas UN-REDD, Jakarta. http://ukp.go.id/informasi-publik/cat_view/21-redd [Accessed 26 March 2012].

Schmink, M. and C.H. Wood. 1992. Contested frontiers in Amazonia. New York: Columbia University Press.

Scott, J.C. 1998. Seeing like a state: how certain schemes to improve the human condition have failed. New Haven: Yale University Press.

Strydom, L. 2006. Growing biofuel: A biodiesel entrepreneur's checklist for anyone considering entering this infant industry. Available from: http://www.docstoc.com/docs/ 42720536/Growing-Biofuel-A-BIODIESEL-ENTREPRENEURS-CHECKLIST-FORANYONE [Accessed 7 February 2012].

Supriyanto, 2007. Menanti Kelapa Sawit Jadi Komoditas Rakyat Pontianak Post, 7/4/2009, http://www.pontianakpost.com/index.php?mib=berita.detail\&id=18401 [Accessed 7 May 2009].

Suyanto, S. et al., 2009. Analysis of local livelihoods from past to present in the Central Kalimantan ex-mega rice project area. Working paper 94. World Agroforestry Centre. Bogor, Indonesia: World Agroforestry Centre-ICRAF, SEA Regional Office.

Tang, Y., J.-S. Xie and S. Geng. 2010. Marginal land-based biomass energy production in China. Journal of Integrative Plant Biology, 52, 112-121.

Tempo. 2011. Matahari di atas Manggala. Tempo No. 4017/27-3 July 2011, Jakarta pp. 26-30.

Teoh, C.H. 2010. Key sustainability issues in the palm oil sector. A Discussion Paper for multistakeholders consultations. Commissioned by the World Bank Group. The World Bank, The International Finance Corporation, Washington D.C.

Timmer, C.P. 1993. Rural bias in the East and South-East Asian rice economy: Indonesia in comparative perspective. Journal of Development Studies, 29(4), 149-176.

Tsing, A.L. 2005. Friction: an ethnography of global connection. Princeton: Princeton University Press.

UN. 2010. The right to food. The interim report of the Special Rapporteur on the right to food. Available from: http://www.ohchr.org/Documents/Issues/Food/A.66.262_en.pdf [Accessed 12 January 2012].

USDA. 2009. Indonesia: Palm oil production to continue. USDA Commodity Intelligence Report. March 19, 2009. http://www.pecad.fas.usda.gov/highlights/2009/03/Indonesia/ [Accessed 12 January 2012]. 
USDA. 2010. Indonesia: Rising global demand fuels palm oil expansion. Commodity Intelligence Report. Available from: http://www.pecad.fas.usda.gov/highlights/2010/10/ Indonesia/, USDA Foreign Agricultural Service [Access 12 January 2012].

Vatn, A. and A. Angelsen. 2009. Options for a national REDD+ architecture. In: A. Angelsen, et al., eds. Realising REDD+: National strategy and policy options. Bogor, Indonesia: Center for International Forestry Research (CIFOR). pp. 7-74.

Vel, J.A.C. 2008. Miracle solution or imminent disaster? Jatropha biofuel production in Sumba, East Nusa Tenggara. Inside Indonesia, 91. Jan-Mar 2008. Available from: http:// www.insideindonesia.org/weekly-articles-91-jan-mar-2008/miracle-solution-or-imminentdisaster-01031629 [Accessed 7 February 2012].

Vel, J.A.C. and S. Makambombu. 2010. Access to agrarian justice in Sumba, Eastern Indonesia. Law, Social Justice and Global Development Journal, 15. Available from: http:// www.go.warwick.ac.uk/elj/lgd/20010_1/vel_makambombu [Accessed 7 February 2012].

Verchot, L.V. and E. Petkova. 2009. The State of REDD Negotiations: consensus points, option for moving forward and research needs to support the process. Bogor, Indonesia: Center for International Forestry Research (CIFOR).

Wallace, J. and I.P. Williamson. 2006. Building land markets. Journal of Land Use Policy, 23, $123-135$.

World Bank. 2011. Indonesia REDD+ Readiness Preparation Support. Washington, DC: The World Bank.

\begin{abstract}
John McCarthy lectures in the Australian National University's Crawford School of Economics and Government and is a Fellow at the University's Research School of Asia and the Pacific. John carries out research into agrarian change, land tenure, food security, environmental governance and natural resource policy. He is the author of The fourth circle: $a$ political ecology of Sumatra's rainforest frontier (Stanford University Press, 2006). His current research grants are concerned with agrarian transitions and oil palm, and social capital, livelihoods and food security. This article was written under a fellowship from the Koninklijk Instituut voor Taal-, Land- en Volkenkunde (KITLV), Leiden University. Email: john.mccarthy@anu.edu.au
\end{abstract}

Jacqueline Vel is a socio-legal studies researcher at the Van Vollenhoven Institute for Law, Governance and Development of Leiden University. Since 2010, she is coordinator of the international, interdisciplinary research cluster 'JARAK: the commoditization of an alternative biofuel crop in Indonesia' in the Indonesian-Dutch research program 'Agriculture beyond Food'. She worked in Sumba for 6 years. Her works include Uma politics: an ethnography of democratization in West Sumba, Indonesia 1986-2006 (2008), Uma Economy (PhD thesis, 1994; revised Indonesian translation 2010) and articles about local politics, land rights, and access to justice. Website: http://law.leiden.edu/organisation/ metajuridica/vvi/staff/jacqueline-vel.html; Email: j.a.c.vel@law.leidenuniv.nl

Suraya Afiff is a lecturer in the Department of Anthropology Graduate Program, Faculty of Social and Political Sciences at the University of Indonesia. Since 2009, she also serves as the head of the Center for Anthropology Studies in the same university. Her focus of study includes issues of land tenure and conflicts, environmental and agrarian movements, the political economy of environmental change, and recently also REDD in Indonesia. Since 2010, she is a postdoctoral researcher at KITLV (Leiden) in the cluster 'JARAK: the commoditization of an alternative biofuel crop in Indonesia' in the Indonesia-Dutch research program 'Agriculture Beyond Food'. Email: safiff@gmail.com 